\title{
The Chemical States of Color-Induced Cations in Tourmaline Characterized by X-Ray Photoelectron Spectroscopy
}

\author{
Ming Li, ${ }^{1,2}$ Hanlie Hong $\mathbb{D}^{1},{ }^{1}$ Ke Yin, ${ }^{1}$ Chaowen Wang, ${ }^{3}$ Feng Cheng, ${ }^{1}$ and Qian Fang ${ }^{1}$ \\ ${ }^{1}$ School of Earth Sciences, China University of Geosciences, Wuhan, China \\ ${ }^{2}$ Department of Gemmology, Jinling Institute of Technology, Nanjing, China \\ ${ }^{3}$ Gemmological Institute, China University of Geosciences, Wuhan, China
}

Correspondence should be addressed to Hanlie Hong; honghl8311@aliyun.com

Received 17 November 2017; Revised 5 February 2018; Accepted 22 March 2018; Published 2 May 2018

Academic Editor: Vincenza Crupi

Copyright (c) 2018 Ming Li et al. This is an open access article distributed under the Creative Commons Attribution License, which permits unrestricted use, distribution, and reproduction in any medium, provided the original work is properly cited.

In order to better understand the effect of transition metal cations on color of tourmaline, X-ray photoelectron spectroscopy was used to investigate the species, chemical state, site occupancy, and chemical environment of color-induced metal cations in colorful tourmaline samples from Minas Gerais State, Brazil. Our results showed that the colorful tourmalines usually contained a small amount of transition metal elements, and a colorful tourmaline sample had several transition metal cations; however, the color of tourmaline resulted from the transition metal cations in the Y site of the crystal structure. The pink color of tourmaline was associated with $\mathrm{Mn}^{2+}$ in the $\mathrm{Y}$ site coordinating with $\mathrm{F}$; the yellow color was derived from $\mathrm{Ni}^{2+}$ in the $\mathrm{Y}$ site binding to $\mathrm{O}$; the green color was associated with $\mathrm{Fe}^{3+}$ in the $\mathrm{Y}$ site coordinating with $\mathrm{O}, \mathrm{OH}$, and $\mathrm{F}$; the rose red color originated from $\mathrm{Mn}^{2+}$ and $\mathrm{Ni}^{2+}$ in the $\mathrm{Y}$ site in which $\mathrm{Mn}^{2+}$ coordinated with $\mathrm{O}$ and $\mathrm{F}$, and $\mathrm{Ni}^{2+}$ coordinated with $\mathrm{O}$; and the blue color was derived from $\mathrm{Fe}^{3+}$ and $\mathrm{Mn}^{2+}$ in the $\mathrm{Y}$ site in which $\mathrm{Fe}^{3+}$ binded to $\mathrm{O}, \mathrm{OH}$, and $\mathrm{F}$ and $\mathrm{Mn}^{2+}$ binded to $\mathrm{F}$. Additionally, other transition metal cations were also observed in colorful tourmalines, but all these species occupied the $\mathrm{Z}$ site of the structure. In the pink and yellow samples, $\mathrm{Fe}$ and $\mathrm{Cr}$ were observed in $\mathrm{Fe}^{3+}$ and $\mathrm{Cr}^{3+}$; in the rose red sample, $\mathrm{Fe}$ was also found in $\mathrm{Fe}^{3+}$; in the blue sample, $\mathrm{Cr}$ was present in $\mathrm{Cr}^{3+}$; in the green sample, $\mathrm{Mn}, \mathrm{Ni}$, and $\mathrm{Cu}$ were found in $\mathrm{Mn}^{2+}, \mathrm{Ni}^{2+}$, and $\mathrm{Cu}^{2+}$, respectively. The color of tourmaline was induced from the absorption of the $\mathrm{d}$ - $\mathrm{d}$ transition of transition metals in the crystal structure, as charge transfer tended to occur between cations occupying different coordination positions.

\section{Introduction}

Tourmaline, commonly known as "Bixi" in China, is a precious medium-high-grade gem material. It is termed the "fallen rainbow" and valued by consumers for its extremely rich and unique colors. Tourmaline is a polar silicate mineral crystal with no center of symmetry and has complex chemical compositions. Fluorine, hydroxyl, and other anions in addition to the silicate root are often found with boric acid and cations in the structure, such as $\mathrm{Cr}, \mathrm{Mn}$, and $\mathrm{Fe}$, which have a wide range of isomorphic replacement. Tourmaline colors are extremely rich and variable [1-8]. Tourmaline can be colorless, pink, rose red, red, yellow, brown, green, dark green, light blue, blue, purple, and black, with color changes associated with variable chemical compositions. The mechanism that determines the color of tourmaline has been a perennial problem in mineralogy. For example, some researchers believe that pink originated from the absorption of $\mathrm{d}$ - $\mathrm{d}$ transition of $\mathrm{Mn}$ in the octahedron, while others hypothesize it is the result of a color heart, similar to smoky quartz [9]. However, Chaudhry and Howie [10] did not find Mn when analyzing pink tourmaline from Devonshire, which rebuts the hypothesis that pink is caused by the absorption of the $\mathrm{d}-\mathrm{d}$ transition of $\mathrm{Mn}^{3+}$. Babińska et al. [11] used electron paramagnetic resonance (EPR) to identify $\mathrm{Mn}^{2+}$ in elbaite, $\mathrm{Fe}^{3+}$ in dravite and schorl. They also found that the color and spectral characteristic of tourmaline that contains $\mathrm{Fe}$ did not change regularly with varied Fe contents. This phenomenon suggests that the color of those tourmaline results from the charge transfer between $\mathrm{Fe}^{2+}$ and $\mathrm{Fe}^{3+}[12,13]$. Through research on pink and green tourmaline using the XPS (X-ray photoelectron spectroscopy) method, Hong et al. [14] hypothesized that 
transition metal cations in different colored tourmalines have the same chemical state, for example, $\mathrm{Fe}^{3+}, \mathrm{Mn}^{4+}, \mathrm{Ti}^{4+}$, and $\mathrm{Cr}^{3+}$, but with different coordination ions. That may be the primary reason for the color difference. Petrov [15] showed that the violet color in tourmaline is caused by the absorption of the $\mathrm{d}$-d transition for $\mathrm{Cr}^{3+}$. A large number of studies have shown that the varied color in tourmaline is related to the various transition metal cation species, especially the state of these cations. However, researchers still have differing opinions on the attribution of the absorption belt, chemical state of the ions, and color mechanism [16, 17]. This study researched the chemical states of metal cations using X-ray photoelectron spectroscopy and explored the species, valence state, and especially coordination ion and site occupancy of color-induced metal cations, in pink, yellow, green, rose red, and blue tourmaline.

\section{Materials and Methods}

Six pieces of tourmaline, representative of different colors, were selected as samples from Minas Gerais, Brazil (Figure 1). Five samples were colored pink, yellow, green, rose red, and blue, and one colorless sample was chosen as the baseline sample.

Photoelectron spectroscopy can provide both qualitative and quantitative results, including the chemical state of the surface elements of the sample by testing the kinetic energy of the photoelectron and Auger electrons emitted from the solid surface from the photoelectric and Auger effects. This series of experiments was conducted on an AXIS-ULTRA DLD-600W X-ray photoelectron spectrometer at the Huazhong University of Science and Technology Analysis and Testing Center. In order to avoid contamination, the crystal sample was enwrapped with tinfoil and was then broken by a pair of pincers, and the fresh surface was subsequently used for XPS measurement. Test conditions were as follows: $\mathrm{Al} \mathrm{K} \alpha$ $(E=1486.6 \mathrm{eV}) \mathrm{X}$-ray radiation source, instrument vacuum better than $5 \times 10^{-9}$ Torr, scanning step length of $0.05 \mathrm{eV}$, and counting time of $500 \mathrm{~ms}$. The charge displacement is fixed, and the C1s electron binding energy value $(285 \mathrm{eV})$ was used for equipment calibration. The range of energy spectrum was $0-1200 \mathrm{eV}$. Because the subject of analysis was primarily trace elements, we carefully scanned the photoelectron spectra of these trace elements and repeated 15 times to improve the resolution.

For X-ray diffraction (XRD) analysis, the tourmaline sample was broken and further ground manually to powder using an agate mortar. XRD measurement was performed in a Philips PW 3710 diffractometer operated at $\mathrm{CuK} \alpha$ radiation $(45 \mathrm{kV}, 35 \mathrm{~mA})$ and scan rate of $4^{\circ} 2 \theta / \mathrm{min}$ at the State Key Laboratory of Geological Processes and Mineral Resources, China University of Geosciences (Wuhan).

\section{Results and Discussion}

3.1. Crystal Chemistry of Tourmaline. The X-ray photoelectron spectroscopy results for the tourmaline samples are shown in Figure 2. Based on the standard electron binding energy data of the elements, although the tourmaline samples

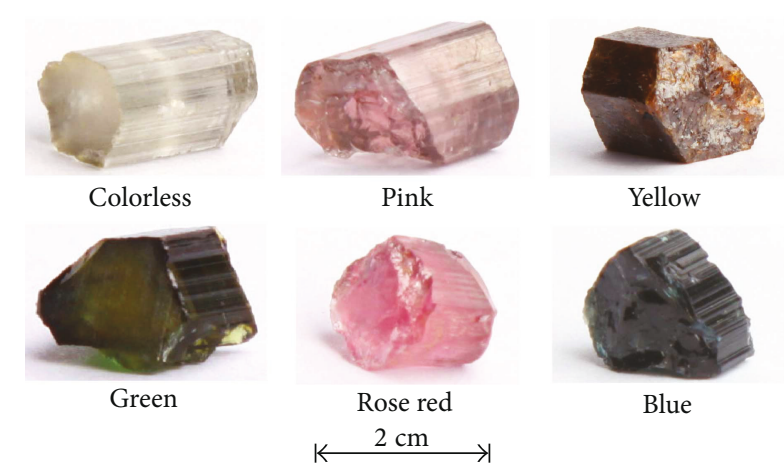

FIGURE 1: Tourmaline samples.

differ in color, their main chemical components are similar; they all contain $\mathrm{Al}, \mathrm{Si}, \mathrm{Na}, \mathrm{O}, \mathrm{F}, \mathrm{B}$, and other elements. Results from the further slow scan confirm that these tourmaline samples also contain a small amount of $\mathrm{Cr}, \mathrm{Mn}, \mathrm{Fe}$, $\mathrm{Ni}$, and $\mathrm{Cu}$, and other elements, but no $\mathrm{Li}$ or Be.

Tourmaline is a ring borosilicate mineral; its crystal chemical formula is generally recognized as [18] $\mathrm{XY}_{3} \mathrm{Z}_{6}\left[\mathrm{~T}_{6} \mathrm{O}_{18}\right][-$ $\left.\mathrm{BO}_{3}\right]_{3} \mathrm{~V}_{3} \mathrm{~W}$, where the $\mathrm{X}$ site is primarily occupied by large radius metal cations, such as $\mathrm{Na}^{+}, \mathrm{K}^{+}$, and $\mathrm{Ca}^{2+}$. Sometimes, $\mathrm{Mg}^{2+}$ or a vacancy can be found in the $\mathrm{X}$ site. Its coordination number is 9. The $\mathrm{Y}$ site is occupied by $\mathrm{Al}^{3+}, \mathrm{Fe}^{3+}, \mathrm{V}^{3+}, \mathrm{Cr}^{3+}$, $\mathrm{Mg}^{2+}, \mathrm{Mn}^{2+}, \mathrm{Fe}^{2+}, \mathrm{Cu}^{2+}, \mathrm{Zn}^{2+}, \mathrm{Li}^{+}$, and $\mathrm{Ti}^{4+}$; it can also contain some vacancies and has a coordination number of 6 [19]. The $\mathrm{Z}$ site is occupied by $\mathrm{Al}^{3+}, \mathrm{Fe}^{3+}, \mathrm{V}^{3+}, \mathrm{Cr}^{3+}, \mathrm{Mg}^{2+}$, and $\mathrm{Fe}^{2+}$ and has a coordination number of 6 . The $\mathrm{T}$ site is occupied by $\mathrm{Si}$, can be partly replaced by $\mathrm{Al}, \mathrm{B}$, and $\mathrm{Be}$, and has a coordination number of 4 . The coordination number of $\mathrm{B}$ is 3 , and there is no clear substitution. The W (O1) site is occupied by $\mathrm{OH}, \mathrm{F}$, and $\mathrm{O}$ and has a coordination number of 3. The $\mathrm{V}(\mathrm{O} 3)$ site is occupied by $\mathrm{OH}$ and $\mathrm{O}$ and has a coordination number of 3 [20].

In the tourmaline structure, the $\left[\mathrm{TO}_{4}\right]$ tetrahedron forms $\left[\mathrm{T}_{6} \mathrm{O}_{18}\right]^{12-}$ a hexagonal ring. In comparison, the cation occupying the $\mathrm{Y}$ position of the crystal structure forms a brucite structure with $\mathrm{O}^{2-}, \mathrm{OH}^{-}$, and $\mathrm{F}^{-}$. Three $\left[\mathrm{Y}-\mathrm{O}_{4} \mathrm{VW}\right]$ coordination octahedrons are connected to the hexagonal ring by sharing an $\mathrm{O}^{2-}$ on the top of $\left[\mathrm{TO}_{4}\right]$. The intersection of the three octahedrons lies on the central axis of the hexagonal ring, which is the $\mathrm{W}$ position. $\left[\mathrm{BO}_{3}\right]$ is found between the six square rings and octahedral layer, which shares one $\mathrm{O}^{2-}$ with the octahedral layer. These complex anions are connected to each other by $\mathrm{Z}$ ions. The $\left[\mathrm{Z}-\mathrm{O}_{5} \mathrm{~V}\right]$ octahedron and $\left[\mathrm{Y}-\mathrm{O}_{4} \mathrm{VW}\right]$ octahedron share one edge [21]. The $\mathrm{X}$ ions are located in the upper space of the hexagonal. Bosi [7] has shown that the $\mathrm{W}(\mathrm{O} 1)$ anion is mainly bonded to the metal cation in the $\mathrm{Y}$ site of the tourmaline crystal structure. Therefore, the metal cation in the $\mathrm{Y}$ site is mainly coordinated with the $\mathrm{W}(\mathrm{O} 1)$ anion, while the metal cation in the $\mathrm{Z}$ site does not bind to the $\mathrm{W}(\mathrm{O} 1)$ anion.

3.2. The Chemical State of Trace Elements. The tourmaline color is often associated with a very small amount of metal cations [22]. The fine analysis results showing the characteristic energy spectra for the metal cations are shown in Figures 3-7. 


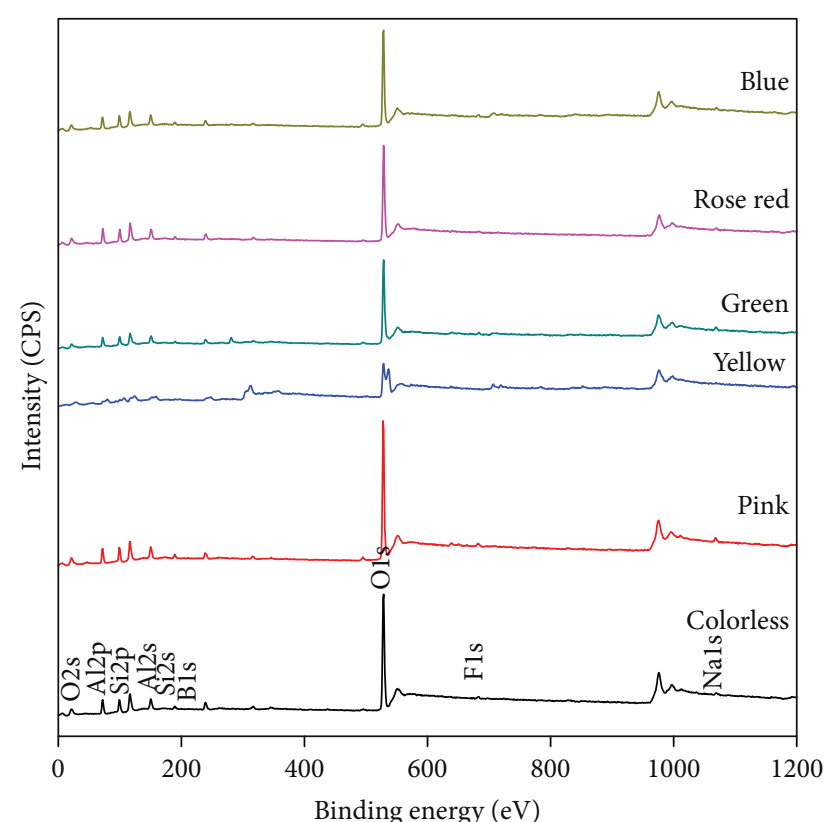

Figure 2: X-ray photoelectron spectra of tourmaline samples.

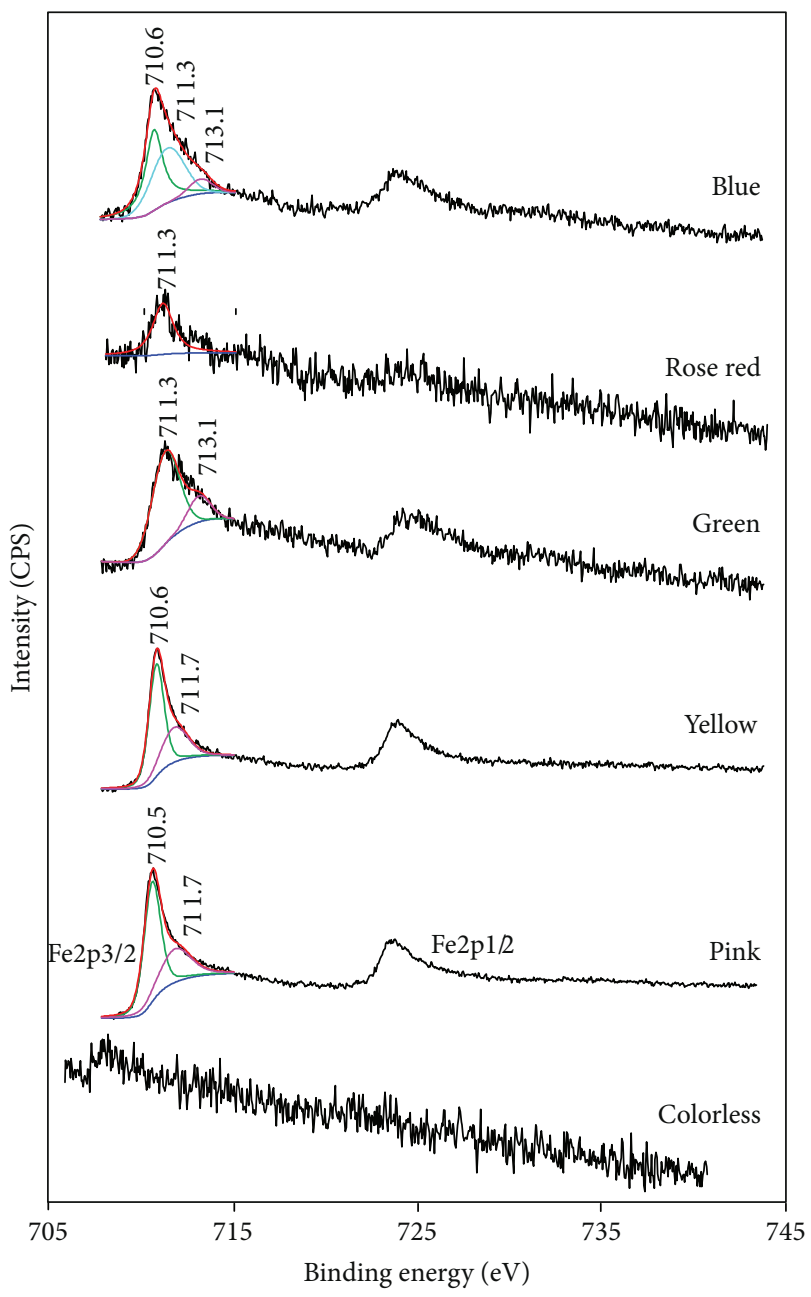

FIgURE 3: XPS spectra for Fe2p.

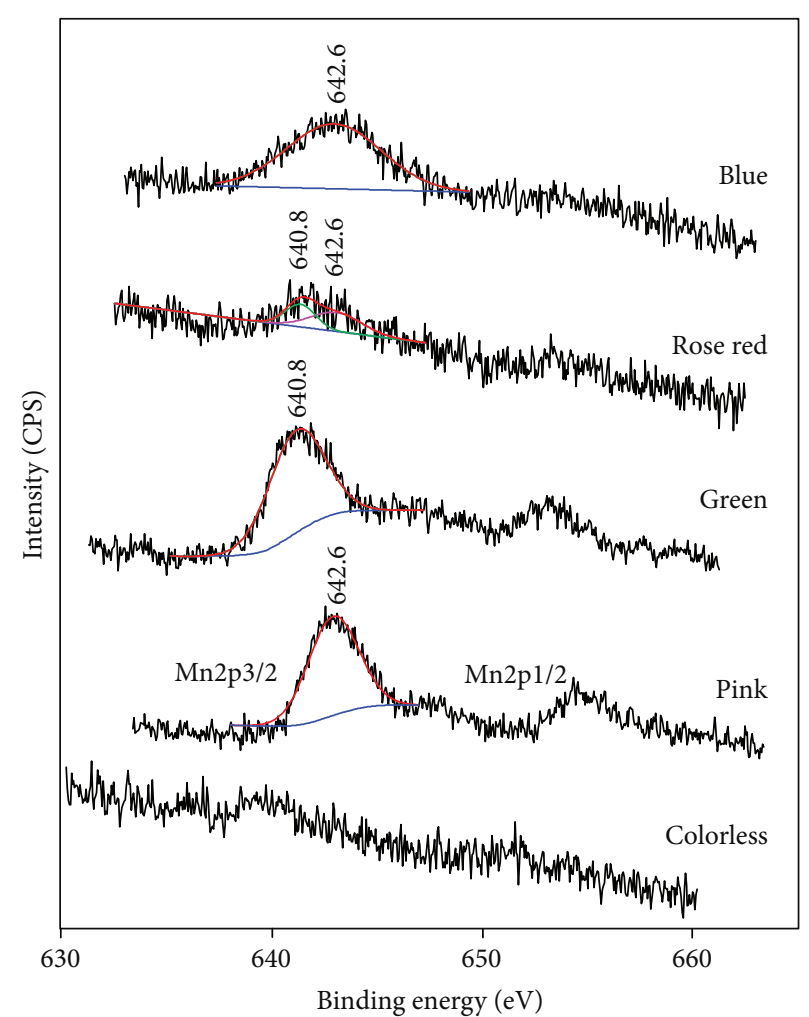

FIgURE 4: XPS spectra for Mn.

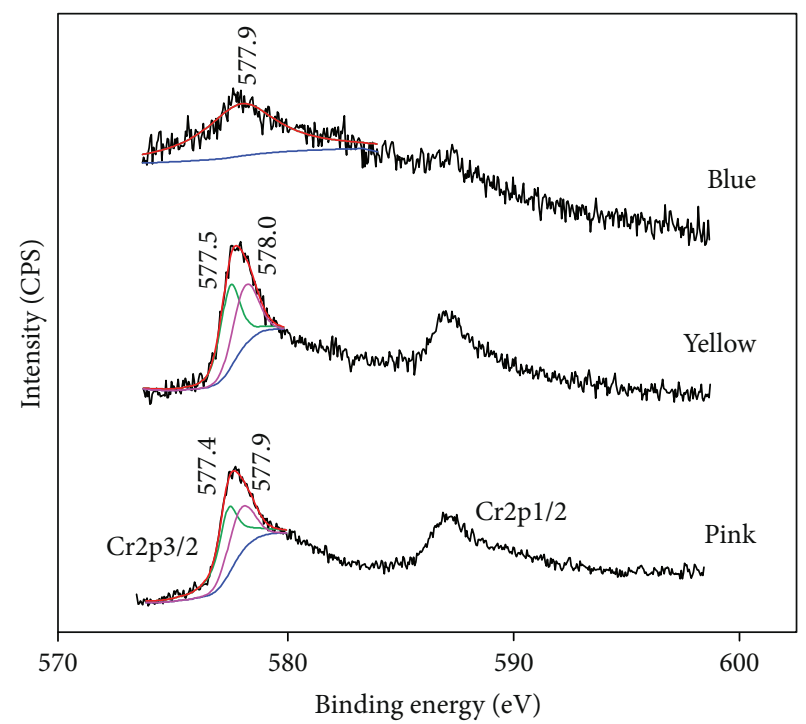

FIGURE 5: XPS spectra for Cr2p.

Figure 3 shows the XPS spectrum for Fe2p. The peaks of the energy spectrum line for the pink, yellow, and blue samples are clearly higher than those of colorless, green, and rose red samples. The peak heights reflect the abundance of Fe in tourmaline crystal. Therefore, the abundance of $\mathrm{Fe}$ in the pink, yellow, and blue samples is clearly higher than in the colorless, green, and rose red samples. For the colorless contrast sample, there is no significant spectral peak, indicating the lack of Fe. Furthermore, different samples have different 


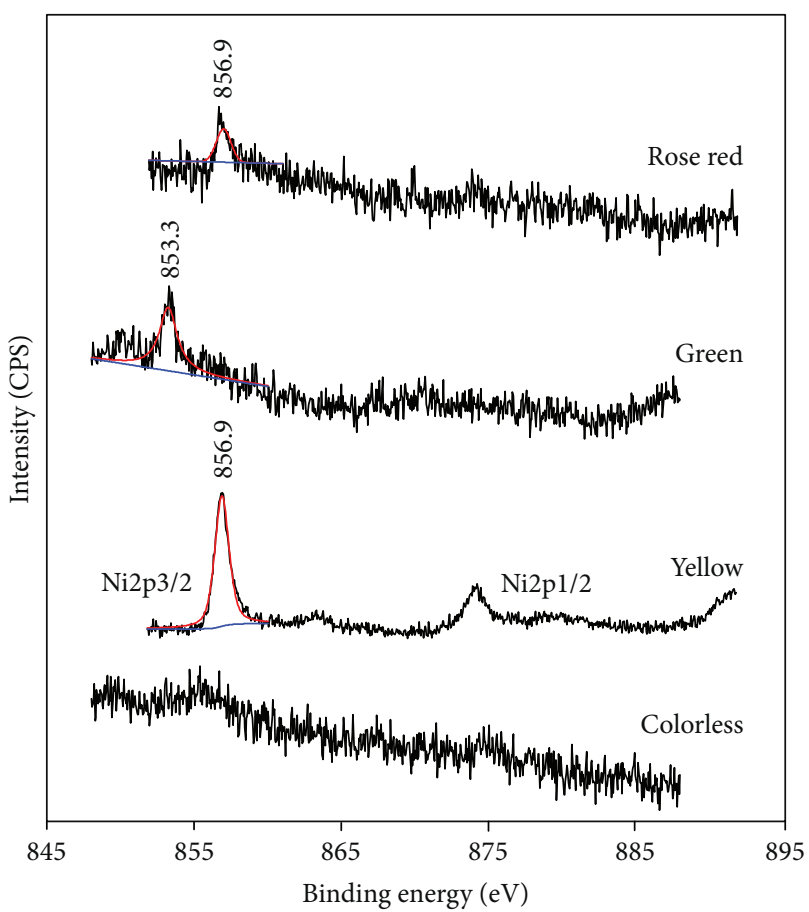

Figure 6: XPS spectra for Ni2p.

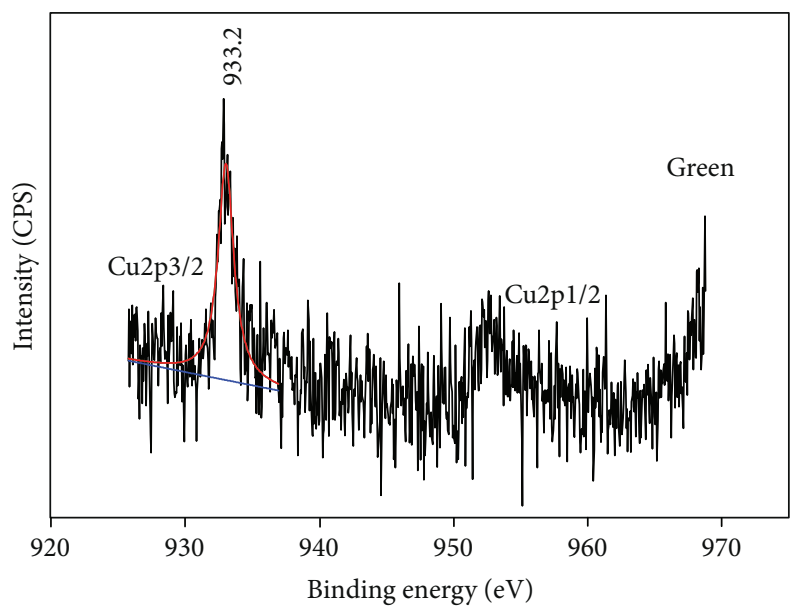

FIGURE 7: XPS spectrum for Cu2p.

peak positions. The Fe2p3/2 peaks of these samples show clearly an asymmetric shape, with one shoulder peak in the higher binding energy side, suggesting that the Fe2p3/2 line is an overlapping peak. By fitting calculation [23], the peak was decomposed into two peaks at 710.5 and $711.7 \mathrm{eV}$ for the pink sample, at 710.6 and $711.7 \mathrm{eV}$ for the yellow sample, at 711.3 and $713.1 \mathrm{eV}$ for the green sample, and at 710.6, 711.3 , and $713.1 \mathrm{eV}$ for the blue sample, respectively. For the rose red sample, the $\mathrm{Fe} 2 \mathrm{p} 3 / 2$ signal is significantly weak and is present as a single peak at $711.3 \mathrm{eV}$.

The different binding configurations and estimated percentages of $\mathrm{Fe}$ are reported in Table 1 . The electron binding energies of $\mathrm{Fe} 2 \mathrm{p} 3 / 2$ in $\mathrm{Fe}_{2} \mathrm{O}_{3}, \mathrm{FeOOH}$, and $\mathrm{NaFeO}_{2}$ are $710.7,711.3$, and $711.8 \mathrm{eV}$, respectively. In the pink, yellow, and blue samples, the electron binding energy of the
TABle 1: Different binding configurations, estimated atomic percentages, and occupancy site of $\mathrm{Fe}, \mathrm{Mn}, \mathrm{Cr}$, and $\mathrm{Ni}$.

(a)

\begin{tabular}{lccccc}
\hline & $\mathrm{Fe}^{3+}-\mathrm{O}$ & $\begin{array}{c}\mathrm{Fe}^{3+}-\mathrm{O} \\
+\mathrm{OH}\end{array}$ & $\mathrm{Fe}^{3+}-\mathrm{O}(-\mathrm{Na})$ & $\mathrm{Fe}^{3+}-\mathrm{F}$ & Site \\
\hline Pink & $66 \%$ & $/$ & $34 \%$ & $/$ & $\mathrm{Z}$ \\
Yellow & $65 \%$ & $/$ & $35 \%$ & $/$ & $\mathrm{Z}$ \\
Green & $/$ & $82 \%$ & $/$ & $18 \%$ & $\mathrm{Y}$ \\
Rose red & $/$ & $100 \%$ & $/$ & $/$ & $\mathrm{Z}$ \\
Blue & $48 \%$ & $43 \%$ & $/$ & $9 \%$ & $\mathrm{Y}$ \\
\hline
\end{tabular}

(b)

\begin{tabular}{lccc}
\hline & $\mathrm{Mn}^{2+}-\mathrm{O}$ & $\mathrm{Mn}^{2+}-\mathrm{F}$ & Site \\
\hline Pink & $/$ & $100 \%$ & $\mathrm{Y}$ \\
Green & $100 \%$ & $/$ & $\mathrm{Z}$ \\
Rose red & $41 \%$ & $59 \%$ & $\mathrm{Y}$ \\
Blue & $/$ & $100 \%$ & $\mathrm{Y}$ \\
\hline
\end{tabular}

(c)

\begin{tabular}{lccc}
\hline & $\mathrm{Cr}^{3+}-\mathrm{O}$ & $\mathrm{Cr}^{3+}-\mathrm{O}(-\mathrm{B})$ & Site \\
\hline Pink & $64 \%$ & $36 \%$ & $\mathrm{Z}$ \\
Yellow & $60 \%$ & $40 \%$ & $\mathrm{Z}$ \\
Blue & $/$ & $100 \%$ & $\mathrm{Z}$ \\
\hline
\end{tabular}

(d)

\begin{tabular}{lccc}
\hline & $\mathrm{Ni}^{2+}-\mathrm{O}$ & $\mathrm{Ni}^{2+}-\mathrm{O}(-\mathrm{Al})$ & Site \\
\hline Yellow & $/$ & $100 \%$ & $\mathrm{Y}$ \\
Green & $100 \%$ & $/$ & $\mathrm{Z}$ \\
Rose red & $/$ & $100 \%$ & $\mathrm{Y}$ \\
\hline
\end{tabular}

strongest Fe2p3/2 component are 710.5, 710.6, and $710.6 \mathrm{eV}$, respectively, coinciding with the electron binding energy of $\mathrm{Fe} 2 \mathrm{p} 3 / 2$ in $\mathrm{Fe}_{2} \mathrm{O}_{3}$, indicating that $\mathrm{Fe}$ is mainly in the $\mathrm{Fe}^{3+}$ chemical state and coordinates with $\mathrm{O}$. The Fe2p3/ 2 peak at $711.7 \mathrm{eV}$ for pink and yellow samples is approximately consistent with the electron binding energy of $\mathrm{Fe} 2 \mathrm{p} 3 / 2$ in $\mathrm{NaFeO}_{2}$, indicating that part of $\mathrm{Fe}$ coordinates with $\mathrm{O}$ and $\mathrm{O}$ also binds with $\mathrm{Na}$ in the crystal structure of these samples. The binding energy of Fe2p3/2 in the rose red sample is $711.3 \mathrm{eV}$, in agreement with the electron binding energy of $\mathrm{Fe} 2 \mathrm{p} 3 / 2$ in $\mathrm{FeOOH}$, indicating that $\mathrm{Fe}$ mainly bonds with $\mathrm{O}$ and $\mathrm{OH}$. However, the electron binding energy of $F e 2 \mathrm{p} 3 / 2$ at $713.1 \mathrm{eV}$ in the green and blue samples is slightly lower than the value $713.9 \mathrm{eV}$ for Fe2p3/2 in $\mathrm{FeF}_{3}$ [24], indicating that $\mathrm{Fe}$ is in the $\mathrm{Fe}^{3+}$ chemical state and mainly bonds with $\mathrm{F}, \mathrm{O}$, and $\mathrm{OH}$. The relative proportion of $\mathrm{Fe}$ in different coordinate states is listed in Table 1.

The colorless, rose red, and blue samples show extremely weak Mn2p peaks, while the pink and green samples have an obvious Mn2p peak, indicating that the colorless, rose red, and blue samples contain significantly a small amount of $\mathrm{Mn}$ in the crystals compared to the pink and green samples 
(Figure 4). The Mn2p peaks exhibit generally symmetric shapes for pink, green, and blue samples, and the Mn2p electron binding energy is $640.8 \mathrm{eV}$ for the green sample and $642.6 \mathrm{eV}$ for pink and blue samples. On the contrary, the $\mathrm{Mn} 2 \mathrm{p} 3 / 2$ peak of the rose red sample is asymmetric, which is decomposed into two peaks at 640.8 and $642.6 \mathrm{eV}$, respectively, by peak fitting.

The different binding configurations and estimated percentages of $\mathrm{Mn}$ in various chemical states are reported in Table 1. According to the energy spectrum for Mn standard compounds, in bivalent manganese oxides and bivalent manganese fluorides, the electron binding energies of $\mathrm{Mn} 2 \mathrm{p} 3 / 2$ are 640.8 and $642.6 \mathrm{eV}$, respectively. In the pink and blue samples, the electron binding energy of $\mathrm{Mn} 2 \mathrm{p} 3 / 2$ approximately agrees with that of bivalent manganese fluorides, indicating that $\mathrm{Mn}$ is in the $\mathrm{Mn}^{2+}$ state and mainly coordinated with F. In the green sample, the electron binding energy of $\mathrm{Mn} 2 \mathrm{p} 3 / 2$ agrees with that of bivalent manganese oxides, indicating that $\mathrm{Mn}$ is in the $\mathrm{Mn}^{2+}$ chemical state and mainly coordinates with $\mathrm{O}$. In the rose red sample, the Mn2p3/2 peak is asymmetric and could be decomposed into two peaks at 640.8 and $642.6 \mathrm{eV}$, consistent with those of bivalent manganese oxides and bivalent manganese fluorides, respectively, suggesting that $\mathrm{Mn}$ is in the $\mathrm{Mn}^{2+}$ chemical state and coordinates with both $\mathrm{O}$ and $\mathrm{F}$. Also, for pink, rose red, and blue samples, $\mathrm{Mn}^{2+}$ occupies the $\mathrm{Y}$ site, whereas for the green sample it occupies the $\mathrm{Z}$ site in the crystal structure.

Figure 5 shows the XPS spectrum for Cr2p. Colorless, green, and rose red samples do not show the energy spectrum peak for $\mathrm{Cr}$. In the blue sample, the energy spectrum peak of $\mathrm{Cr}$ is significantly weak, while it is relatively strong in the spectra of the pink and yellow samples. In the blue sample, the Cr2p displays a symmetric shape and situates at the position of $577.9 \mathrm{eV}$. In the pink and yellow samples, the $\mathrm{Cr} 2 \mathrm{p} 3 / 2$ peak show a notably asymmetric shape, which was decomposed into two peaks at 577.4 and $577.9 \mathrm{eV}$ for the pink sample and at 577.5 and $578.0 \mathrm{eV}$ for the yellow sample, respectively. The electron-binding energies of $\mathrm{Cr} 2 \mathrm{p} 3 / 2$ in $\mathrm{Cr}_{2} \mathrm{O}_{3}$ and $\mathrm{CrBO}_{3}$ are about 577.4 and $577.95 \mathrm{eV}$. Obviously, $\mathrm{Cr}$ in tourmaline is present in the $\mathrm{Cr}^{3+}$ state and coordinates with $\mathrm{O}$; however, in pink and yellow samples, part of $\mathrm{Cr}$ also binds with $\mathrm{O}$ and $\mathrm{B}$ (Table 1). From the $\mathrm{Cr} 2 \mathrm{p} 3 / 2$ electronbinding energies of the color tourmaline samples, it can be inferred that $\mathrm{Cr}^{3+}$ occupies the $\mathrm{Z}$ site of the crystal structure.

Pink and blue samples do not show energy peaks of $\mathrm{Ni}$ in the energy spectrum (Figure 6). In the colorless sample, the electron binding energy peak of $\mathrm{Ni}$ is extremely weak, while it is quite strong for the yellow, green, and rose red samples, which all show a good symmetric shape. The yellow and rose red samples have the same Ni2p3/2 electron-binding energy peak at $856.9 \mathrm{eV}$, while the green sample has the Ni2p3/2 peak at $853.3 \mathrm{eV}$. The $\mathrm{Ni} 2 \mathrm{p} 3 / 2$ peak position at $856.9 \mathrm{eV}$ for the yellow and rose red samples is consistent with that of the $\mathrm{Ni}$ standard compound $\mathrm{Al}_{2} \mathrm{NiO}_{4}(857.0 \mathrm{eV})$, suggesting that $\mathrm{Ni}$ is present in the form of $\mathrm{Ni}^{2+}$ and coordinates with $\mathrm{O}$, and $\mathrm{O}$ also binds to $\mathrm{Al}$ in the structure [14]. Therefore, Ni clearly occupies the $\mathrm{Y}$ site and mainly coordinates with $\mathrm{O}$ in yellow and rose red samples [18]. In the green sample, the Ni2p3/2 electronbinding energy is $853.3 \mathrm{eV}$, in good agreement with that in
$\mathrm{NiO}$, indicating that $\mathrm{Ni}$ in green tourmaline is present in $\mathrm{Ni}^{2+}$ state and is predominantly bonded to $\mathrm{O}$ and only occupies the Z $\mathrm{Z}$ site of the crystal structure (Table 1).

Figure 7 shows the XPS spectrum for Cu2p. Only the green sample shows a weak energy peak for $\mathrm{Cu}$ at $933.2 \mathrm{eV}$. The peak is generally symmetric, in good agreement with the $\mathrm{Cu} 2 \mathrm{p} 3 / 2$ electron-bonding energy $(933.2 \mathrm{eV})$ in $\mathrm{CuO}$. This result indicates that $\mathrm{Cu}$ is present in the form of $\mathrm{Cu}^{2+}$ and mainly coordinates with $\mathrm{O}$ in the green sample.

\subsection{Influence of Chemical State on the Tourmaline Color. The} mineral crystal color is primarily caused by the transition metal cation in the crystal composition, impurity defects, intrinsic defects, structural distortions, color centers, and charge transfer. The effects of the reflection, diffraction, and diffuse and interference of light can also result in coloration $[22,25]$. In addition, a pigment ion with different coordination numbers in the crystal structure may generate different colors. For example, $\mathrm{Co}^{2+}$ makes minerals appear red when the coordination number is 6 , whereas it makes minerals show a special blue when the coordination number is 4 . It is widely believed that Fe-rich tourmaline appears dark green, dark blue, dark brown, or black. Mg-rich tourmaline appears yellow or brown. Li-rich and Mn-rich tourmaline appears rose red or light blue, and Cr-rich tourmaline is dark green [26].

The XPS results for colorless, pink, yellow, green, rose red, and blue tourmaline samples show that a color tourmaline sample usually contains various kinds of transition metal ions; however, the transition metal cations in the $\mathrm{Y}$ site are obviously different between the color tourmaline samples. For example, the pink sample contains $\mathrm{Fe}^{3+}, \mathrm{Cr}^{3+}$, and $\mathrm{Mn}^{2+}$, while the yellow sample contains $\mathrm{Fe}^{3+}, \mathrm{Cr}^{3+}$, and $\mathrm{Ni}^{2+}$. However, in the crystal structure, both $\mathrm{Fe}^{3+}$ and $\mathrm{Cr}^{3+}$ occupy the $\mathrm{Z}$ site, and $\mathrm{Mn}^{2+}$ and $\mathrm{Ni}^{2+}$ occupy the $\mathrm{Y}$ site. The previous investigation showed that the color of tourmaline resulted from the transition metal cations in the $\mathrm{Y}$ site of the structure [9]. Thus, the difference in color between the pink and yellow samples is probably dominated by the presence of $\mathrm{Mn}^{2+}$ or $\mathrm{Ni}^{2+}$ in the Y site. Although $\mathrm{Fe}^{3+}, \mathrm{Mn}^{2+}$, $\mathrm{Ni}^{2+}$, and $\mathrm{Cu}^{2+}$ were present in the green tourmaline sample, only $\mathrm{Fe}^{3+}$ occupies the $\mathrm{Y}$ site and coordinates with $\mathrm{O}, \mathrm{OH}$, and $\mathrm{F}$, while other components $\mathrm{Mn}^{2+}, \mathrm{Ni}^{2+}$, and $\mathrm{Cu}^{2+}$ occupy the $\mathrm{Z}$ site and coordinate with $\mathrm{O}$. Therefore, the green color of tourmaline is dominantly related to $\mathrm{Fe}^{3+}$ in the $\mathrm{Y}$ site coordinating with $\mathrm{O}, \mathrm{OH}$, and $\mathrm{F}$. The rose red tourmaline sample contains $\mathrm{Mn}^{2+}, \mathrm{Ni}^{2+}$, and $\mathrm{Fe}^{3+}$, with the occupation of $\mathrm{Fe}^{3+}$ in the $\mathrm{Z}$ site and both $\mathrm{Mn}^{2+}$ and $\mathrm{Ni}^{2+}$ in the $\mathrm{Y}$ site in the crystal structure. $\mathrm{Fe}^{3+}$ coordinates primarily with $\mathrm{O}$ and $\mathrm{OH}$, and $\mathrm{Mn}^{2+}$ coordinates with $\mathrm{O}$ and $\mathrm{F}$, while $\mathrm{Ni}^{2+}$ binds to O. Obviously, the rose red color of tourmaline is derived from both $\mathrm{Mn}^{2+}$ and $\mathrm{Ni}^{2+}$. The blue tourmaline sample contains $\mathrm{Fe}^{3+}$, $\mathrm{Mn}^{2+}$, and $\mathrm{Cr}^{3+}$, but $\mathrm{Cr}^{3+}$ occupies the $\mathrm{Z}$ site and both $\mathrm{Fe}^{3+}$ and $\mathrm{Mn}^{2+}$ occupy the $\mathrm{Y}$ site of the crystal structure. $\mathrm{Cr}^{3+}$ coordinates primarily with $\mathrm{O}, \mathrm{Fe}^{3+}$ coordinates with $\mathrm{O}, \mathrm{OH}$, and $\mathrm{F}$, while $\mathrm{Mn}^{2+}$ coordinates with $\mathrm{F}$. The blue color of tourmaline is derived from both $\mathrm{Fe}^{3+}$ and $\mathrm{Mn}^{2+}$ in the crystal.

According to crystal field theory, the characteristic color of many gem minerals is related to the crystal field transition 

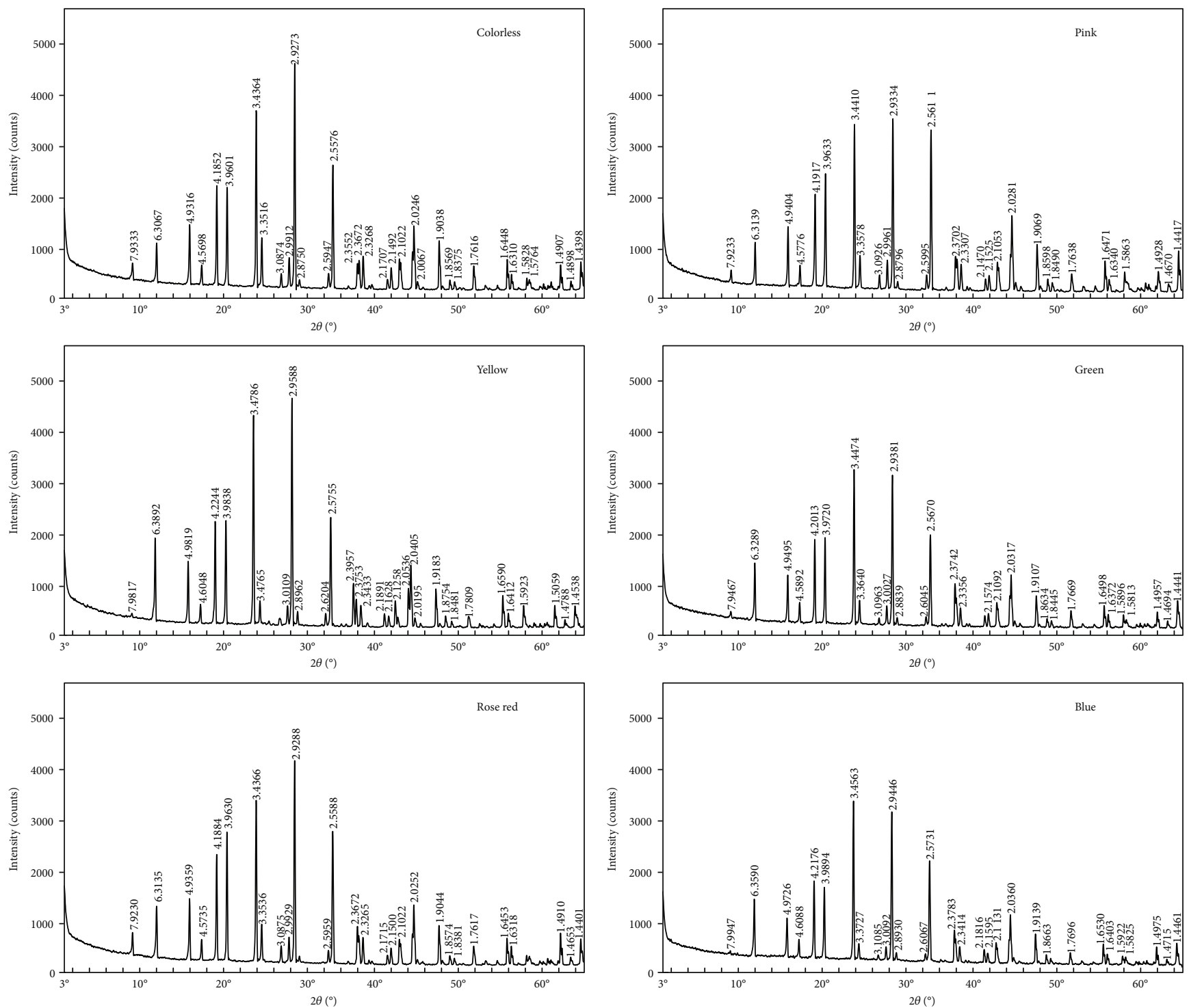

FIGURE 8: XRD spectra of tourmaline samples.

of $\mathrm{Cr}$ [27]. The electron configuration of $\mathrm{Cr}^{3+}$ is $3 \mathrm{~d}^{3}$. Splitting the $3 \mathrm{~d}^{3}$ electron energy level in the octahedron can lead to an energy-level transition, which is directly associated with mineral colors [25]. Furthermore, the distance between atoms directly exerts on the colors of minerals. With a long distance between $\mathrm{Cr}^{3+}$ and $\mathrm{O}$, the splitting parameter of the octahedron crystal field is small, and thus the mineral is green; otherwise, the mineral is red. However, in the crystal structure of tourmaline, the transition metal cations related to color are located mainly in the $\mathrm{Y}$ site [9]. The charge transfer is the electron exchange between ions in the crystal activated by photons, which may occur between metal cations (M-M), or between $\mathrm{O}^{2-}$ and a metal cation. The charge transfers between $\mathrm{O}$ and a metal cation often involves high energy; for example, the long-wave tail in the charge transfer between $\mathrm{O}^{2-}$ and $\mathrm{Fe}^{3+}$ can occur under visible light, thus affecting color of the mineral. The peak position of the charge transfers between $\mathrm{O}$ and a metal cation depends on the species, coordination number, and coordination symmetry of the cation.
The color of many green silicate minerals is often associated with the peak position of the charge transfer between $\mathrm{O}^{2-}$ and $\mathrm{Fe}^{3+}$. The charge transfer between transition metal cations often occurs between coedge or coplanar coordination octahedrons; however, the color-induced transition metal cations occupy the same $\mathrm{Y}$ site in the structure and charge transfer between metal cations (M-M) is not expected [28].

The XRD results are shown in Figure 8. The sharp peaks of all the tourmaline samples show that all samples are generally well crystallized; however, the colorless tourmaline sample with no detected trace elements in the structure displays the most intensive reflections compared to other samples especially for the weak peaks in the patterns, suggesting that the colorless sample has the most well-crystallized crystal and ordered structure [29]. On the contrary, the colorful tourmaline samples with certain amounts of trace elements show relatively lower peak intensity and/or different peak ratios of characteristic reflections, indicating the presence of impurity defects and structural distortion in the crystals due to the 
substitutions of trace elements. Therefore, differences in the chemical environment, including the types of coordination anions, impurity defects, and structural distortion, can lead to different electronic transitions, which may also be the reason for color differences in tourmaline.

\section{Conclusions}

A color tourmaline sample usually contains several species of transition metal elements. However, there is distinctive difference in element of the transition metals in the $\mathrm{Y}$ site between different color samples. The pink color of tourmaline is caused by $\mathrm{Mn}^{2+}$ occupying the $\mathrm{Y}$ site of the crystal structure, while green is attributed to $\mathrm{Fe}^{3+}$ occupying the Y site. The yellow color of tourmaline is related to $\mathrm{Ni}^{2+}$ bonding primarily with $\mathrm{O}$, while rose red is derived from both $\mathrm{Mn}^{2+}$ and $\mathrm{Ni}^{2+}$ in the $\mathrm{Y}$ site. The blue color is attributed to $\mathrm{Fe}^{3+}$ and $\mathrm{Mn}^{2+}$ in the Y site. The charge transfer between cation pairs is unlikely to take place in the color-induced cations of the sole $\mathrm{Y}$ site, and the color of tourmaline is probably induced from the absorption of the $\mathrm{d}$ - $\mathrm{d}$ transition of transition metals in the crystal structure instead.

\section{Conflicts of Interest}

The authors declare that there is no conflict of interest with any institution or funding body.

\section{Acknowledgments}

This work was supported by the Natural Science Foundation of China (Grant nos. 41472041 and 41772032), National Natural Science Youth Foundation of China (Grant no. 41602037), Natural Science Youth Foundation of Hubei (Grant no. 2016CFB183), the Postdoctoral Science Foundation of China (Grant no. 2015M582301), and Fundamental Research Funds for the Central Universities, China University of Geosciences (Wuhan) (CUG160848).

\section{References}

[1] F. F. Foit Jr., "Crystal chemistry of alkali-deficient schorl and tourmaline structural relationships," American Mineralogist, vol. 74, no. 3-4, pp. 422-431, 1989.

[2] F. C. Hawthorne, D. J. MacDonald, and P. C. Burns, "Reassignment of cation occupancies in tourmaline: $\mathrm{Al}-\mathrm{Mg}$ disorder in the crystal structure of dravite," American Mineralogist, vol. 78, no. 3-4, pp. 265-270, 1993.

[3] F. Cámara, L. Ottolini, and F. C. Hawthorne, "Crystal chemistry of three tourmalines by SREF, EMPA, and SIMS," American Mineralogist, vol. 87, no. 10, pp. 1437-1442, 2002.

[4] J. J. Wang, X. F. Tao, and W. J. Wang, "Color characteristics of green tourmaline from Xinjiang," Acta Petrologica et Mineralogica, vol. 24, no. 4, pp. 319-323, 2005.

[5] Y. J. Hou, H. L. Hong, H. J. Xue, and X. L. Zhang, "Gemmological and mineralogical characteristics of colored tourmaline from Minas Gerais State, Brazil," Journal of Gems \& Gemmology, vol. 10, no. 3, pp. 8-13, 2008.

[6] F. Bosi, T. Balić-Žunić, and A. A. Surour, "Crystal structure analyses of four tourmaline specimens from the Cleopatra's
Mines (Egypt) and Jabal Zalm (Saudi Arabia), and the role of $\mathrm{Al}$ in the tourmaline group," American Mineralogist, vol. 95, no. 4, pp. 510-518, 2010.

[7] F. Bosi, "Stereochemical constraints in tourmaline: from a short-range to a long-range structure," The Canadian Mineralogist, vol. 49, no. 1, pp. 17-27, 2011.

[8] W. Han, J. Ke, H. Chen, and K. Yin, "Diffuse reflectance spectroscopy of red colored 'Laowo Stone'," Spectroscopy and Spectral Analysis, vol. 36, no. 8, pp. 26-34, 2016.

[9] P. G. Manning, "An optical absorption study of the origin of colour and pleochroism in pink and brown tourmalines," The Canadian Mineralogist, vol. 9, no. 5, pp. 678-690, 1969.

[10] M. N. Chaudhry and R. A. Howie, "Lithium tourmalines from the Meldon aplite, Devonshire, England," Mineralogical Magazine, vol. 40, no. 315, pp. 747-751, 1976.

[11] J. Babińska, K. Dyrek, A. Pieczka, and Z. Sojka, "X and Q band EPR studies of paramagnetic centres in natural and heated tourmaline," European Journal of Mineralogy, vol. 20, no. 2, pp. 233-240, 2008.

[12] S. M. Mattson and G. R. Rossman, " $\mathrm{Fe}^{2+}-\mathrm{Fe}^{3+}$ interactions in tourmaline," Physics and Chemistry of Minerals, vol. 14, no. 2, pp. 163-171, 1987.

[13] J. Fan, X. Feng, S. Guo, and X. Liu, "Optical absorption spectra of tourmaline crystals," Journal of the Chinese Ceramic Society, vol. 37, no. 4, pp. 523-531, 2009.

[14] H. L. Hong, J. Li, D. W. Du, Z. Q. Zhong, K. Yin, and C. W. Wang, "Chemical states of colour-induced cations in colourful tourmaline," Journal of Gems \& Gemmology, vol. 13, no. 2, pp. 6-12, 2011.

[15] I. Petrov, "Role of natural radiation in tourmaline coloration: discussion," American Mineralogist, vol. 75, no. 1-2, pp. 237239, 1990.

[16] J. E. S. Bradley and O. Bradley, "Observations on the colouring of pink and green zoned tourmaline," Mineralogical Magazine, vol. 30, no. 220, pp. 26-38, 1953.

[17] W. A. d. Fonseca-Zang, J. W. Zang, and W. Hofmeister, "The Ti-influence on the tourmaline color," Journal of the Brazilian Chemical Society, vol. 19, no. 6, pp. 1186-1192, 2008.

[18] F. C. Hawthorne and D. J. Henrys, "Classification of the minerals of the tourmaline group," European Journal of Mineralogy, vol. 11, no. 2, pp. 201-216, 1999.

[19] F. F. Foit Jr. and P. E. Rosenberg, "Coupled substitutions in the tourmaline group," Contributions to Mineralogy and Petrology, vol. 62, no. 2, pp. 109-127, 1977.

[20] M. Benvenuti, P. Costagliola, P. Lattanzi, and G. Tanelli, "Mineral chemistry of tourmalines from the Bottino mining district, Apuane Alps (Italy)," European Journal of Mineralogy, vol. 3, no. 3, pp. 537-548, 1991.

[21] G. B. Andreozzi, F. Bosi, and M. Longo, "Linking Mössbauer and structural parameters in elbaite-schorl-dravite tourmalines," American Mineralogist, vol. 93, no. 4, pp. 658-666, 2008.

[22] R. I. Mashkovtsev, S. Z. Smirnov, and J. E. Shigley, "The features of the $\mathrm{Cu}^{2+}$-entry into the structure of tourmaline," Journal of Structural Chemistry, vol. 47, no. 2, pp. 252-257, 2006.

[23] M. C. Biesinger, B. P. Payne, A. P. Grosvenor, L. W. M. Lau, A. R. Gerson, and R. S. C. Smart, "Resolving surface chemical states in XPS analysis of first row transition metals, oxides and hydroxides: Cr, Mn, Fe, Co and Ni," Applied Surface Science, vol. 257, no. 7, pp. 2717-2730, 2011. 
[24] C. D. Wagner, W. M. Riggs, L. E. Davis, J. F. Moulder, and G. E. Muilenberg, Handbook of X-Ray Photoelectron Spectroscopy, Perkin-Elmer Corporation, Eden Prairie, MN, USA, 1979.

[25] K. Nassau, "The origins of color in minerals," American Mineralogist, vol. 63, no. 3-4, pp. 219-229, 1978.

[26] B. L. Zhang, Systematic Gemmology, Geological Publishing House, Beijing, China, 2006.

[27] D. L. Wood and K. Nassau, "The characterization of beryl and emerald by visible and infrared absorption spectroscopy," American Mineralogist, vol. 53, no. 5, pp. 777-800, 1968.

[28] F. Chen, C. Y. Lin, H. F. Zhang, and H. S. Xie, Introduction to Mineral Physics, Science Press, Beijing, China, 1995.

[29] F. D. Bloss, Crystallography and Crystal Chemistry: An Introduction, Mineralogical Society of America, Washington, DC, USA, 1994. 

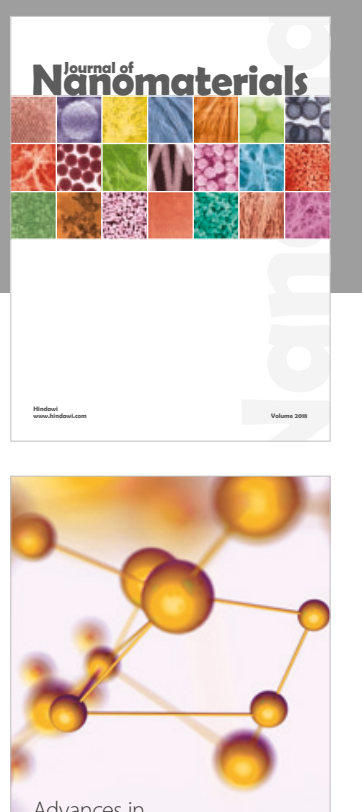

Physical Chemistry
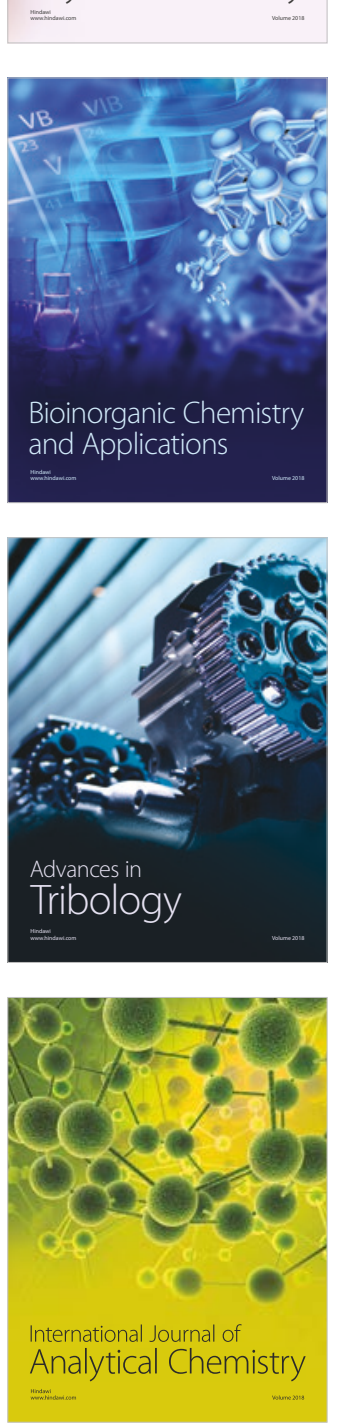

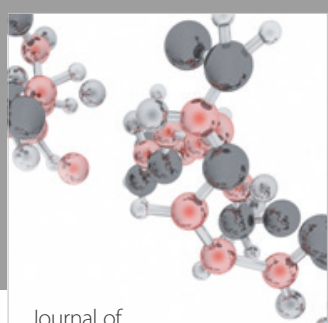

Analytical Methods

in Chemistry

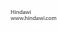

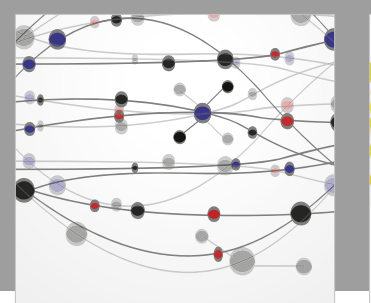

The Scientific World Journal

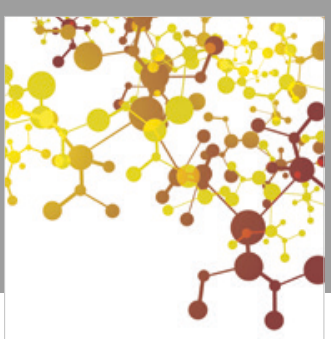

Journal of

Applied Chemistry
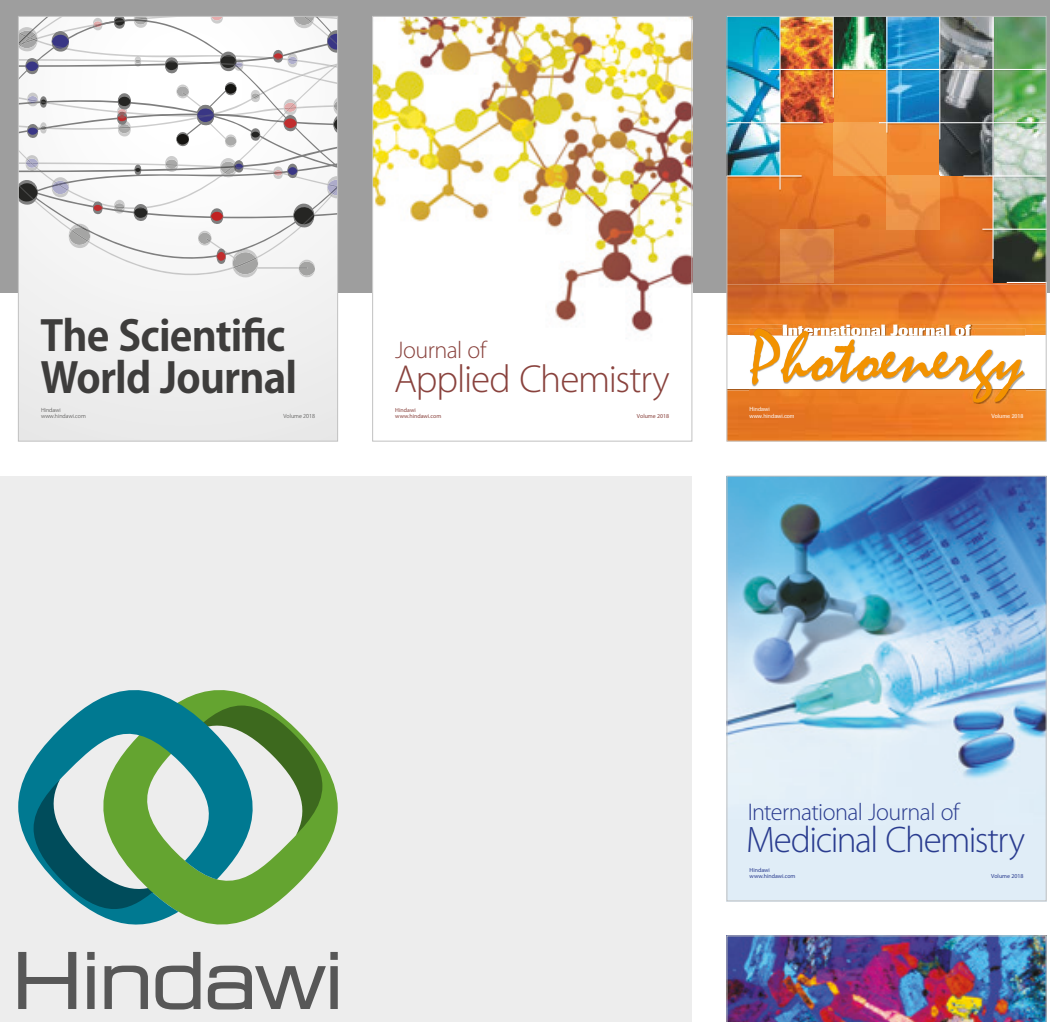

Submit your manuscripts at

www.hindawi.com
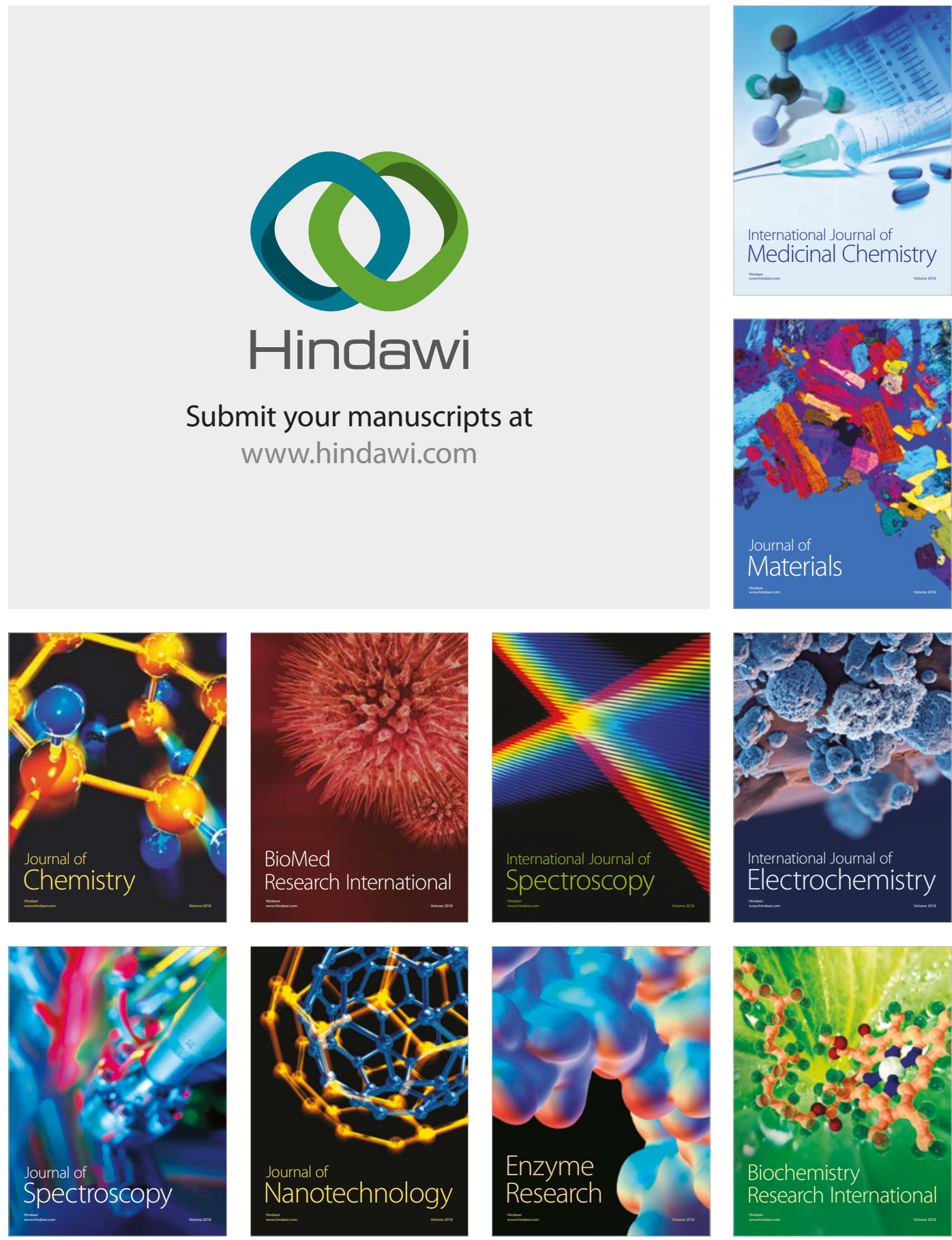
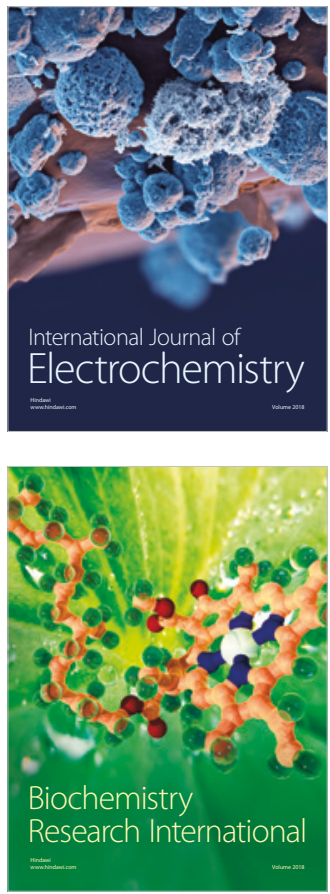